\title{
Edukasi PHBS (Perilaku Hidup Bersih dan Sehat), dan Social/Physical Distancing sebagai Upaya Pencegahan Penularan Virus Corona (Covid-19) pada Keluarga Pra Sejahtera
}

\author{
Fitri Mailani, Rahmi Muthia, Emil Huriani, dan Sovia Susianty \\ Fakultas Keperawatan, Universitas Andalas, Kampus Limau Manis, Padang, 25163. Indonesia \\ E-mail: fitrimailani22@nrs.unand.ac.id
}

Keywords:

Covid-19,

education, family, healthy life

Kata Kunci:

Covid-19, edukasi, keluarga, PHBS

\begin{abstract}
Entering the new normal era, some people think that the threat of Covid-19 is nothing to fear. But in reality the number of new cases of patients infected with Covid-19 is increasing. This proves that awareness of the Corona virus transmission still needs to be improved. Especially for pre-prosperous families whose access to information is limited. Limited health workers providing education to all levels of society are also an obstacle in the midst of this pandemic. The aim of this activity is to increase the knowledge of the underprivileged community about how to prevent the transmission of the Covid-19 virus. The method of implementing this activity is door-to-door education to underprivileged families living in the village of Sungai Buluh Selatan, Kabupaten Padang Pariaman, the majority of who work as factory workers and daily laborers. Education was carried out using the media module/booklet and was carried out for three days, namely 1-3 July, 2020, to 32 pre-prosperous families who had been recommended by the head of the jorong. Education includes how to prevent the transmission of the Covid-19 virus, implement clean and healthy living habits, how to do physical/social distancing and how to use the right cloth masks, and make environmental disinfectants with cheap materials. The results of the evaluation show an increase in family understanding and motivation regarding the prevention of Covid19 transmission. Continuous education is still very much needed, especially for underprivileged families whose access to information sources is limited.
\end{abstract}
ABSTRAK
Memasuki era new normal sebagian masyarakat beranggapan bahwa ancaman Covid-19 sudah tidak perlu ditakuti. Namun kenyataannya angka kasus baru pasien terinfeksi Covid-19 semakin meningkat. Hal ini membuktikan bahwa kewaspadaan terhadap penularan virus Corona masih harus ditingkatkan. Terutama kepada keluarga pra sejahtera yang akses informasinya terbatas. Keterbatasan tenaga kesehatan memberikan edukasi kepada seluruh lapisan masyarakat juga menjadi kendala ditengah pandemi ini. Tujuan dilakukannya kegiatan ini adalah untuk meningkatkan pengetahuan masyarakat pra sejahtera mengenai cara pencegahan penularan virus Covid-19. Metode pelaksanaan kegiatan ini adalah dengan melakukan edukasi dari rumah ke rumah (door to door) kepada keluarga pra sejahtera yang berada di Nagari Sungai Buluh Selatan Kab. Padang Pariaman, yang mayoritas bekerja sebagai pekerja pabrik dan buruh harian. Edukasi dilakukan dengan media modul/booklet dan dilakukan selama tiga hari yaitu tanggal 1-3 Juli 2020, kepada 32 keluarga pra sejahtera yang sudah direkomendasikan oleh kepala 
jorong. Edukasi meliputi cara pencegahan penularan virus Covid-19, menerapkan perilaku hidup bersih dan sehat, cara melakukan physical/social distancing serta cara menggunakan masker kain yang tepat, dan membuat desinfektan lingkungan dengan bahan yang murah. Hasil evaluasi menunjukkan meningkatnya pemahaman dan motivasi keluarga mengenai pencegahan penularan Covid-19. Edukasi berkelanjutan masih sangat dibutuhkan, terutama kepada keluarga pra sejahtera yang akses sumber informasinya terbatas.

\section{PENDAHULUAN}

Virus Corona (Covid-19) telah dinyatakan sebagai pandemi dunia oleh WHO (WHO, 2020). Virus ini bersifat zoonosis atau virus yang ditularkan dari hewan ke manusia (Wang, Z, Qiang, w., Ke, 2020). Virus dan penyakit ini diketahui berawal dari kota Wuhan, Cina sejak Desember 2019. Tanggal 21 Maret 2020, jumlah kasus penyakit ini mencapai angka 275.469 jiwa yang tersebar di 166 negara, termasuk Indonesia (Tim Gugus Tugas Percepatan Penanganan Covid-19, 2020).

Presiden Republik Indonesia telah menyatakan status penyakit ini menjadi tahap Tanggap Darurat pada tanggal 17 Maret 2020. Presiden juga telah mengeluarkan keputusan presiden No. 7 Tahun 2020 tentang gugus tugas percepatan penanganan corona yang dikeluarkan oleh Badan Nasional Penanggulangan Bencana (BNPB). Tanggal 3 Juli 2020 diketahui bahwa sebanyak 60.695 orang positif terjangkit virus Corona yang tersebar di 31 provinsi di Indonesia, 27.568 orang dinyatakan sembuh. Sumatera Barat dinyatakan 775 orang terjangkit Covid-19 per tanggal 4 Juli 2020. Presentasi kematian di Indonesia cukup tinggi yaitu 8,02\%, bahkan dinyatakan salah satu negara dengan angka kematian tertinggi dunia (Tim Gugus Tugas Percepatan Penanganan Covid-19, 2020).

Penularan virus Corona jenis Covid-19 sangat cepat dibandingkan dengan virus sejenisnya, oleh karena itu angka penularannya sangat tinggi. Menurut WHO, Covid-19 menular dari orang ke orang. Caranya dari orang yang terinfeksi virus Corona ke orang yang sehat. Penyakit menyebar melalui tetesan kecil yang keluar dari hidung atau mulut ketika mereka yang terinfeksi virus bersin atau batuk. Tetesan itu kemudian mendarat di benda atau permukaan yang disentuh oleh orang sehat. Lalu orang sehat ini menyentuh mata, hidung atau mulut mereka. Virus Corona juga bisa menyebar ketika tetesan kecil itu dihirup oleh orang sehat ketika berdekatan dengan yang terinfeksi Corona (WHO, 2020).

WHO menyatakan gejala Covid-19 yang paling umum adalah demam, kelelahan, dan batuk kering. Beberapa pasien mungkin mengalami sakit dan nyeri, hidung tersumbat, pilek, sakit tenggorokan atau diare. Gejala-gejala ini bersifat ringan dan terjadi secara bertahap. Meskipun virus ini menyerang saluran pernapasan, keluhan sistem gastrointestinal juga ditemukan pada pasien terinfeksi Covid-19 seperti anorexia, diare, mual muntah, nyeri abdominal pain (Pan et al., 2020). Namun, beberapa orang yang terinfeksi tetapi tidak menunjukkan gejala apa pun dan tak merasa tidak enak badan. Pada kasus berat perburukan secara cepat dan progresif, seperti ARDS, syok septik, asidosis metabolik yang sulit dikoreksi dan perdarahan atau disfungsi sistem koagulasi dalam beberapa hari (Kristianingsih et al., 2019).

Memasuki era new normal sebagian masyarakat beranggapan bahwa ancaman Covid-19 sudah tidak perlu ditakuti. Masyarakat mulai melakukan aktivitas ekonomi dan sosial seperti biasa. Tidak jarang dari masyarakat berada di tempat keramaian tanpa menggunakan masker dan mengikuti protokol kesehatan yang telah disosialisasikan pemerintah. Diketahui bahwa angka kasus baru pasien terinfeksi Covid-19 semakin meningkat. Per tanggal 3 Juli 2020, diketahui adanya 10 kasus baru di provinsi Sumatera Barat dan 1.301 kasus di Indonesia. Hal ini membuktikan bahwa kewaspadaan terhadap penularan virus Corona masih harus ditingkatkan, terutama kepada keluarga pra sejahtera yang akses informasinya terbatas. Keluarga pra 
sejahtera merupakan keluarga yang belum dapat memenuhi kebutuhan dasarnya seperti kebutuhan agama, pangan, sandang dan kesehatan (Dwiyanto, 1998).

Peneliti Institut Teknologi Bandung (ITB) memprediksi, penyebaran Covid-19 di Indonesia akan mencapai puncak pada minggu kedua atau ketiga April dan berakhir akhir Mei atau awal Juni (Putri, G., S., 2020), namun memasuki bulan Juli masih saja ditemukan kasus baru di seluruh provinsi di Indonesia. Artinya edukasi masih tetap harus dilakukan kepada masyarakat mengenai cara mencegah penularan virus Covid-19 disepanjang tahun 2020 ini. Bagi keluarga pra sejahtera akses untuk mendapatkan informasi yang akurat sangat terbatas. Tidak semua keluarga pra sejahtera mempunyai televisi dan smartphone di rumah. Keterbatasan tenaga kesehatan memberikan edukasi kepada seluruh lapisan masyarakat juga menjadi kendala ditengah wabah virus Covid-19 ini. Perlunya edukasi door to door kepada seluruh lapisan masyarakat terutama keluarga pra sejahtera tentunya akan berpengaruh terhadap pemahamannya terhadap pandemi virus Covid-19 ini.

Edukasi dilakukan di Nagari Sungai Buluh Selatan yang berada di Kecamatan Batang Anai, Kabupaten Padang Pariaman, Provinsi Sumatra Barat. Secara geografis Sungai Buluh Selatan berdekatan dengan dengan Bandara Internasional Minangkabau (BIM), dan terletak di perbatasan antara kota Padang dengan Kabupaten Padang Pariaman. Mayoritas masyarakat bekerja sebagai buruh pabrik, dengan keadaan sosial ekonomi menengah ke bawah. Himbauan untuk bekerja di rumah dan melakukan physical/social distancing bagi sebagian masyarakat di Nagari Sungai Buluh Selatan tidak terlalu diperhatikan oleh masyarakat. Pengetahuan yang terbatas dan pekerjaan sebagian besar masyarakat yang merupakan buruh pabrik dan pekerja upahan harian membuat masyarakat tetap bekerja seperti biasa dengan alat pelindung diri yang minimal. Sampai saat ini Nagari Sungai Buluh Selatan masih berada dalam area hijau, meskipun begitu edukasi harus tetap dilaksanakan. Tujuan pelaksanaan kegiatan ini adalah meningkatnya pengetahuan keluarga pra sejahtera tentang cara pencegahan penularan Covid-19 melalui Perilaku Hidup Bersih dan Sehat (PHBS) serta melakukan Physical/Social distancing.

\section{METODE}

Metode pelaksanaan kegiatan ini adalah melakukan edukasi melalui door to door (dari rumah ke rumah) keluarga pra sejahtera. Kegiatan ini dilakukan selama 3 hari yaitu tanggal 1 - 3 Juli 2020. Edukasi dilakukan dengan mengunjungi 32 keluarga pra sejahtera yang direkomendasikan oleh Kepala Jorong dan Wali Nagari. Adapun tahapan pelaksanaan kegiatan yang dilakukan adalah sebagai berikut:

1. Pelaksana bekerjasama dengan Wali Nagari mengidentifikasi keluarga pra sejahtera yang akan diedukasi. Penyuluh berdiskusi dengan perangkat Wali Nagari, keluarga mana saja yang akan diprioritaskan untuk dilakukan edukasi.

2. Menyiapkan media edukasi berupa booklet edukasi "semua keluarga BISA kalahkan Corona" dengan menggunakan bahasa yang mudah dipahami. Materi yang disediakan mengenai Perilaku Hidup Bersih dan Sehat (PHBS), social/physical distancing, teknik menggunakan masker kain, membuat desinfektan lingkungan dengan bahan yang mudah didapatkan, serta tips menghadapi era new normal.

3. Penyuluh melakukan pre test untuk mengetahui pemahaman awal keluarga mengenai pencegahan penularan Covid-19.

4. Pelaksana melakukan edukasi mengenai PHBS dan social/physical distancing kepada keluarga pra sejahtera dengan mengunjungi rumah masing-masing (door to door).

5. Pelaksana mendemonstrasikan penggunaan masker yang benar dan teknik cuci tangan yang tepat. 
6. Pelaksana mengevaluasi pemahaman keluarga mengenai materi yang diberikan. Hasil evaluasi akan ditampilkan secara deskriptif sebagai bukti efektifitas edukasi yang dilakukan.

\section{HASIL DAN PEMBAHASAN}

Kegiatan edukasi dilaksanakan di Nagari Sungai Buluh Selatan pada tanggal 1-3 Juli 2020. Edukasi dilakukan kepada 32 keluarga pra sejahtera. Tim dosen yang melakukan edukasi adalah Ns. Fitri Mailani, M.Kep, Emil Huriani, S.Kp, MN, Ns. Rahmi Muthia, M.Kep dan Ns. Sovia Susianty, M.Kep serta dibantu oleh dua orang mahasiswa. Edukasi yang dilakukan dengan melakukan kunjungan dari rumah ke rumah (door to door) dengan tetap memperhatikan protokol kesehatan dan melakukan physical distancing. Metode ini dipilih karena menghindari kerumunan/ keramaian dan akan sulit menjaga physical/social distancing. Adapun karakteristik keluarga pra sejahtera yang mengikuti program edukasi ini tertera pada Tabel 1.

Tabel 1. Karakteristik anggota keluarga yang mengikuti program edukasi

\begin{tabular}{llll}
\hline \multicolumn{1}{c}{ Karakteristik } & Frekuensi & Persentase (\%) \\
\hline Jenis kelamin & & \\
Laki-laki & 2 & 6,2 \\
Perempuan & 30 & 93,7 \\
\hline Usia & & \\
- Dewasa awal (26-35 tahun) & 5 & 15,6 \\
- Dewasa akhir (36-45 tahun) & 15 & 46,9 \\
- Lansia awal (46-55 tahun) & 6 & 18,7 \\
- Lansia akhir (56-65 tahun) & 6 & 18,7 \\
\hline Status pernikahan & & \\
- Menikah & 26 & 81,2 \\
- Janda/duda & 6 & 18,8 \\
\hline Pekerjaan & & \\
- Pekerja upah harian & 5 & 15,6 \\
- Pedagang rumahan/keliling & 5 & 15,6 \\
- Pekerja/buruh pabrik & 9 & 28,1 \\
- IRT & 13 & 40,6 \\
\hline
\end{tabular}

Dari tabel diatas dapat dilihat bahwa mayoritas anggota keluarga yang mengikuti program edukasi adalah perempuan $(93,7 \%)$ dan rentang usia dewasa akhir (46,9\%), status menikah $(81,2 \%)$ dan pekerjaan Ibu Rumah Tangga $(40,6)$ disusul dengan pekerja/buruh pabrik $(28,2 \%)$.

Peningkatan pengetahuan dinilai secara kuantitatif dan kualitatif. Karena keterbatasan kemampuan membaca dan menulis peserta edukasi, maka kuesioner evaluasi dibacakan dan diisi oleh tim pemberi edukasi. Adapun hasil dari evaluasi pemahaman peserta edukasi digambarkan pada Tabel 2. 
Tabel 2. Gambaran peningkatan pengetahuan sebelum dan sesudah dilakukan edukasi

\begin{tabular}{|c|c|c|c|c|c|c|}
\hline \multirow[t]{2}{*}{$\begin{array}{c}\text { Komponen } \\
\text { Evaluasi } \\
\end{array}$} & \multicolumn{3}{|c|}{$\begin{array}{c}\text { Pre test } \\
\text { n (\%) }\end{array}$} & \multicolumn{3}{|c|}{$\begin{array}{c}\text { Post test } \\
\text { n (\%) }\end{array}$} \\
\hline & $\begin{array}{l}\text { Tidak mampu } \\
\text { menyebutkan }\end{array}$ & $\begin{array}{l}\text { Mampu } \\
\text { menyebutkan } \\
\text { sebagian }\end{array}$ & $\begin{array}{l}\text { Mampu } \\
\text { menjawab } \\
\text { dengan } \\
\text { benar }\end{array}$ & $\begin{array}{l}\text { Tidak mampu } \\
\text { menyebutkan }\end{array}$ & $\begin{array}{l}\text { Mampu } \\
\text { menyebutkan } \\
\text { sebagian }\end{array}$ & $\begin{array}{l}\text { Mampu } \\
\text { menjawab } \\
\text { dengan } \\
\text { benar }\end{array}$ \\
\hline $\begin{array}{l}\text { Coba sebutkan } \\
\text { apa saja gejala } \\
\text { jika terinfeksi } \\
\text { virus Corona? }\end{array}$ & $12(37.5)$ & $17(53,1)$ & $3(9,4)$ & 0 & $8(25)$ & $24(75)$ \\
\hline $\begin{array}{l}\text { Coba sebutkan } \\
\text { bagaimana } \\
\text { seseorang dapat } \\
\text { tertular virus } \\
\text { Corona? }\end{array}$ & $12(37.5)$ & $18(56,3)$ & $2(6,2)$ & 0 & $6(18,8)$ & $\begin{array}{c}26 \\
(81,2)\end{array}$ \\
\hline $\begin{array}{l}\text { Coba sebutkan } \\
\text { apa yang harus } \\
\text { dilakukan untuk } \\
\text { mencegah } \\
\text { tertular virus } \\
\text { Corona? }\end{array}$ & $7(21,9)$ & $24(75)$ & $1(3,1)$ & 0 & $4(12,5)$ & $\begin{array}{c}28 \\
(87,5)\end{array}$ \\
\hline $\begin{array}{l}\text { Coba sebutkan } \\
\text { bagaimana cara } \\
\text { meningkatkan } \\
\text { kekebalan tubuh } \\
\text { agar terhindar } \\
\text { dari terinfeksi } \\
\text { virus Corona? }\end{array}$ & $13(40,6)$ & $17(53,1)$ & $2(6,2)$ & 0 & $15(46,9)$ & $\begin{array}{c}17 \\
(53,1)\end{array}$ \\
\hline $\begin{array}{l}\text { Coba sebutkan } \\
\text { bagaimana cara } \\
\text { memakai masker } \\
\text { kain yang benar? }\end{array}$ & $24(75)$ & $6(18,8)$ & $1(3,1)$ & 0 & $4(12,5)$ & $\begin{array}{c}28 \\
(87,5)\end{array}$ \\
\hline $\begin{array}{l}\text { Coba praktekkan } \\
6 \text { langkah cuci } \\
\text { tangan yang } \\
\text { efektif? }\end{array}$ & $30(93,8)$ & $2(6,2)$ & 0 & 0 & $25(78,1)$ & $7(21,9)$ \\
\hline $\begin{array}{l}\text { Coba sebutkan } \\
\text { apa yang harus } \\
\text { dilakukan di era } \\
\text { "new normal" }\end{array}$ & $15(46,9)$ & $15(46,9)$ & $2(6,2)$ & 0 & $6(18,8)$ & $\begin{array}{c}28 \\
(87,5)\end{array}$ \\
\hline
\end{tabular}

Dari Tabel 2 diatas dapat dilihat bahwa terjadi perubahan yang signifikan pengetahuan sebelum dan sesudah dilakukan edukasi. Edukasi yang dilakukan secara langsung dan dari rumah ke rumah terbukti efektif untuk meningkatkan pengetahuan keluarga. Namun, kekurangan teknik ini adalah membutuhkan waktu yang panjang dan tenaga yang banyak. Peningkatan pengetahuan keluarga secara garis besar dapat dilihat dari grafik dibawah ini (Gambar 1). 


\section{Perbedaan Tingkat Pengetahuan Pre dan Post Dilakukan Edukasi}

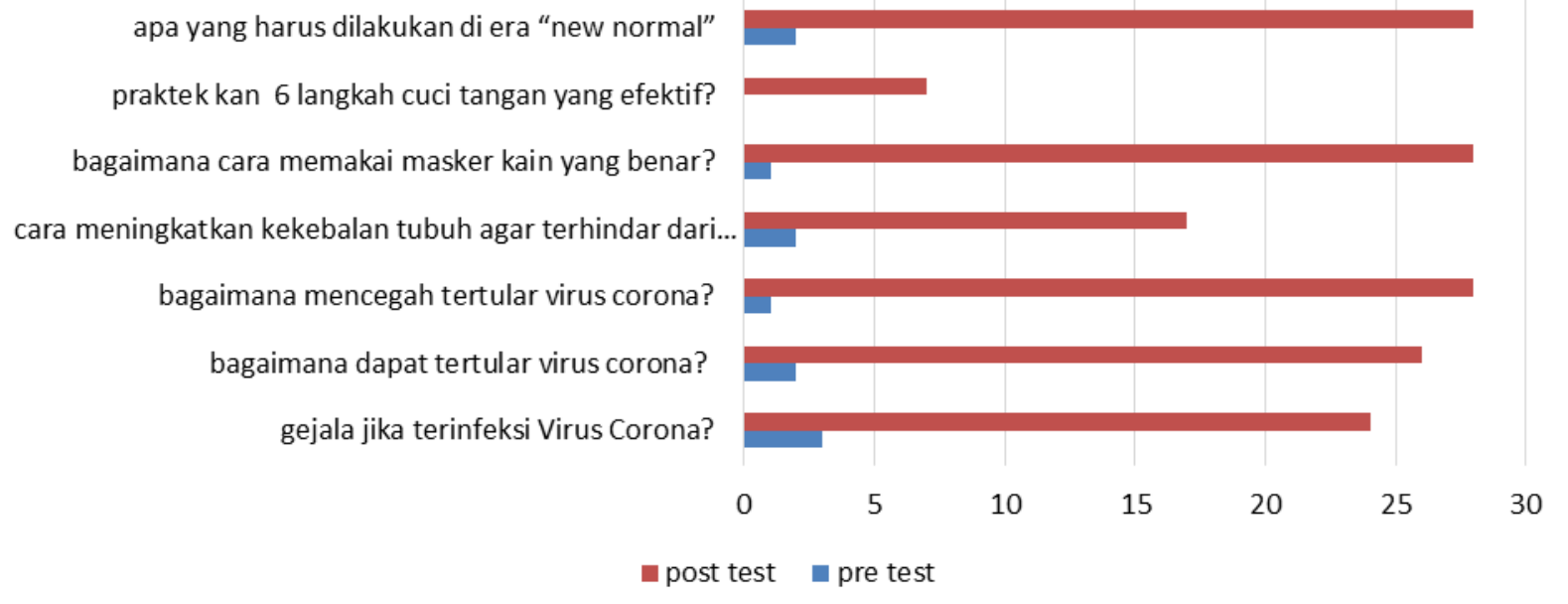

Gambar 1. Grafik perbedaan pengetahuan pre dan post dilakukan edukasi kepada keluarga

Edukasi atau pendidikan secara umum adalah segala upaya yang direncanakan untuk mempengaruhi orang lain baik individu, kelompok, atau masyarakat sehingga mereka melakukan apa yang diharapkan oleh pelaku pendidikan (Notoadmodjo, 2003). Menurut Maulana tahun 2009 bahwa pendidikan kesehatan adalah kegiatan pendidikan yang dilakukan dengan cara menyebarkan pesan, menanamkan keyakinan sehingga masyarakat tidak saja sadar, tahu dan mengerti, tetapi juga mau dan bisa melakukan suatu anjuran yang ada hubungannya dengan kesehatan. Edukasi kesehatan bertujuan meningkatkan pengetahuan dan kesadaran masyarakat untuk memelihara serta meningkatkan kesehatannya sendiri. Oleh karena itu, tentu diperlukan upaya penyediaan dan penyampaian informasi untuk mengubah, menumbuhkan, atau mengembangkan perilaku positif (Maulana, 2009). Edukasi per individual dengan mengunjungi rumah ke rumah terbukti efektif seperti yang dilakukan oleh Pangestika (2019) mengenai edukasi pencegahan penularan TB menunjukkan hasil kegiatan edukasi dari rumah ke rumah terbukti meningkatkan pengetahuan responden tentang pengetahuan penyakit TB (71,4\%), mekanisme penularan penyakit TB $(71,4 \%)$, pengobatan penyakit TB $(80 \%)$ dan cara pencegahan TB dengan PHBS (100\%) dengan rata-rata total peningkatan pengetahuan sebesar 80,7\% (Pangestika et al., 2019).

Pada saat pandemi, tentu saja ada beberapa hal yang harus diperhatikan terkait dengan kunjungan rumah yang dilakukan untuk memberikan edukasi. Adapun beberapa hal yang harus dilaksanakan tim penyuluh adalah melakukan edukasi di green area, artinya daerah atau keluarga yang kita kunjungi tidak sedang dalam pemantauan atau daerah sekitar sedang ada kasus positif terinfeksi virus Corona (red zone). Tim edukasi juga harus melaksanakan protokol kesehatan dengan menggunakan masker, faceshield dan melakukan physical distancing minimal 1 meter.

Media booklet yang menarik dan mudah dipahami dipersiapkan untuk membantu pemahaman keluarga terhadap materi yang diberikan. Materi edukasi ditekankan kepada pencegahan penularan yaitu dengan mencuci tangan lebih sering dengan sabun dan air setidaknya 20 detik atau menggunakan hand sanitizer. Hindari menyentuh mata, hidung, dan mulut dengan tangan yang belum dicuci. Jangan berjabat tangan dan hindari interaksi fisik dekat dengan orang yang memiliki gejala sakit. Tutupi mulut saat batuk dan bersin dengan lengan atas dan ketiak atau dengan tisu lalu langsung buang tisu ke tempat sampah dan segera cuci tangan. Segera mengganti baju/mandi sesampainya di rumah setelah berpergian. Bersihkan dan berikan 
desinfektan secara berkala pada benda- benda yang sering disentuh dan pada permukaan rumah dan perabot (meja, kursi, dan lain-lain), gagang pintu, dan lain-lain.

Tim edukasi juga mengajarkan cara menggunakan masker kain yang benar dan cara membuat cairan desinfektan lingkungan dengan bahan yang mudah ditemui. Pentingnya untuk menerapkan perilaku hidup bersih dan sehat (PHBS) dan melakukan Physichal/Social distancing harus tetap dipertahankan di era kehidupan yang baru ini. Menjaga sistem imunitas diri merupakan hal yang penting untuk diperhatikan, terutama untuk mengendalikan penyakit penyerta (komorbid). Dengan segala keterbatasan keluarga pra sejahtera tim edukasi mengajarkan untuk memanfaatkan segala sesuatu yang mudah didapat dan murah harganya. Seperti makan makanan yang bergizi yang mudah didapat, pembuatan desinfektan lingkungan dari sodium hipoklorit (Bayclin) yang cara membuatnya sudah dijelaskan dengan detail didalam modul edukasi. Di akhir kegiatan edukasi, tim membagikan masker, hand sanitizer dan booklet edukasi kepada keluarga. Pada saat edukasi, seluruh anggota keluarga yang ada di rumah, ikut terlibat dalam proses edukasi.

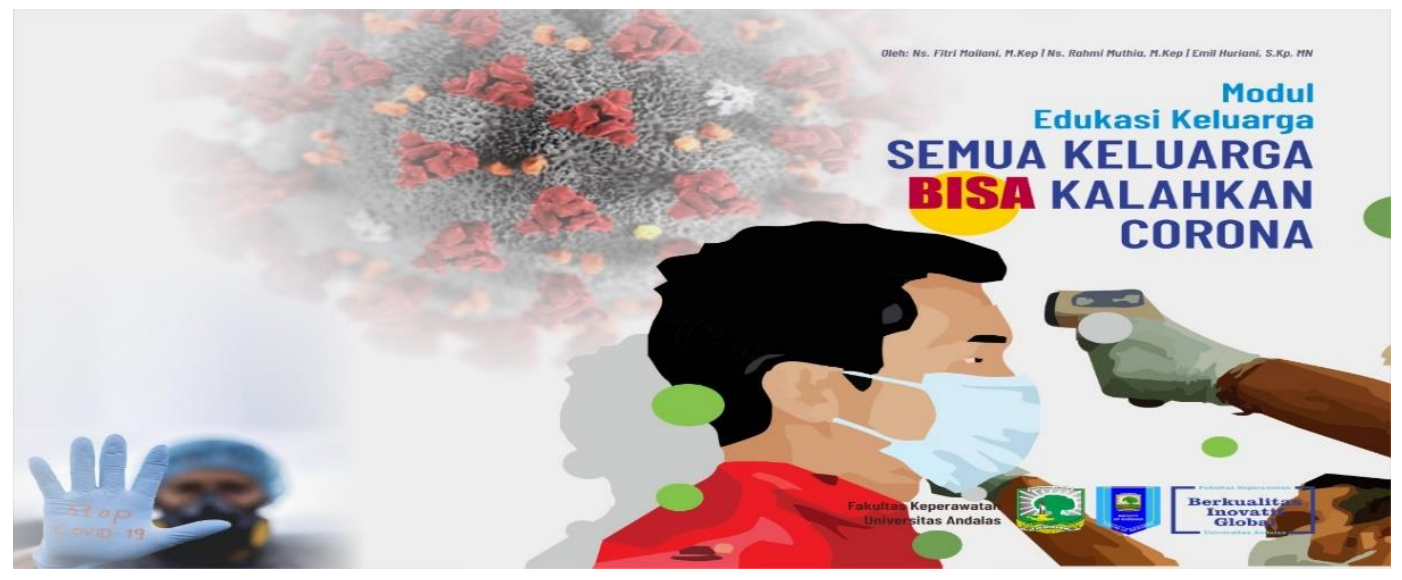

Gambar 2. Modul Edukasi yang digunakan

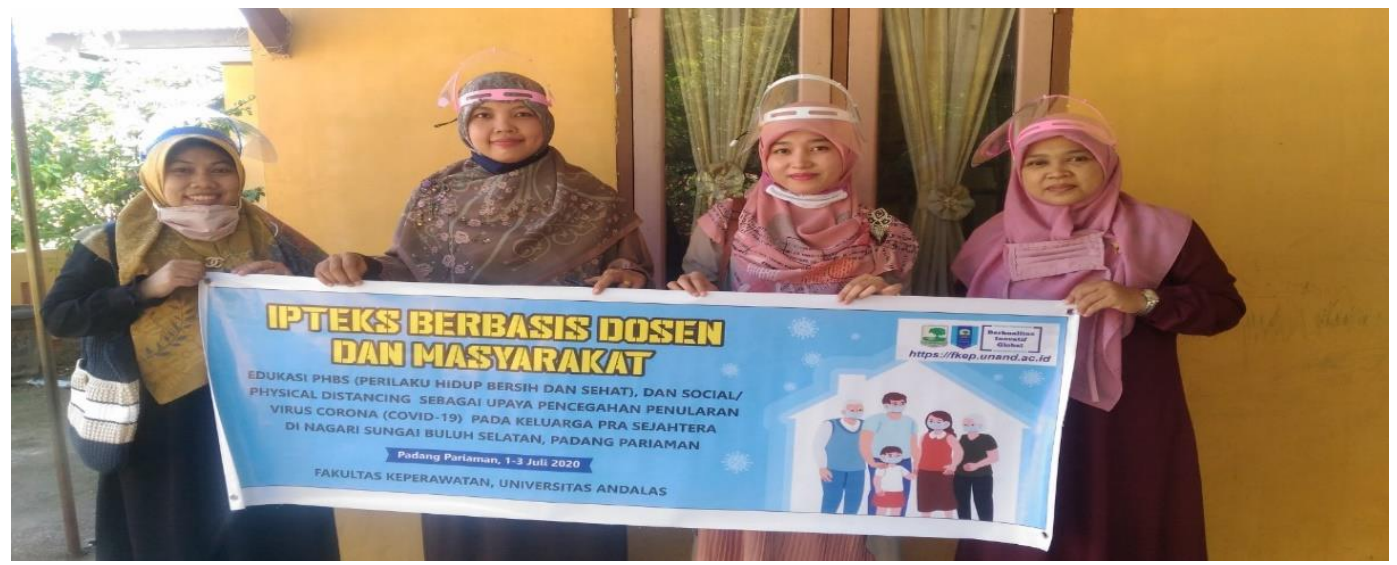

Gambar 3. Tim yang melakukan edukasi 

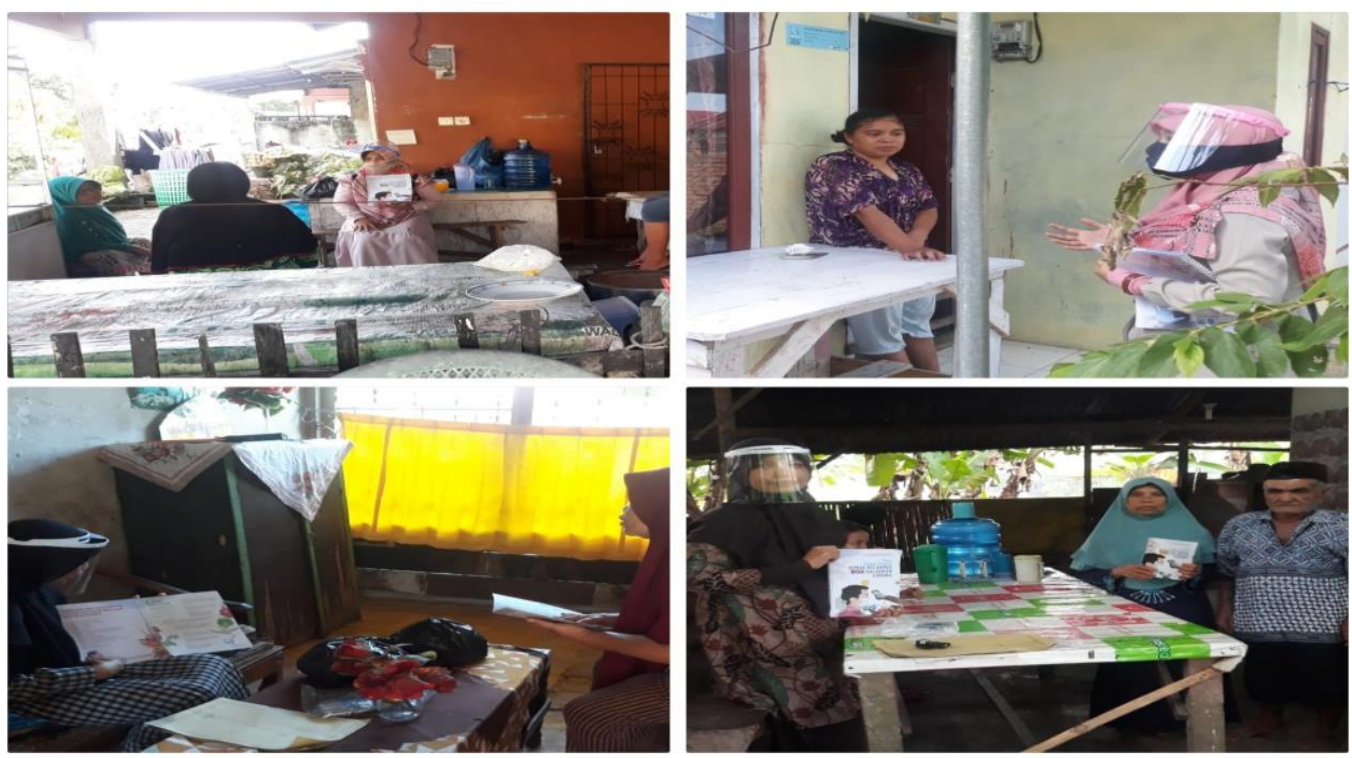

Gambar 4. Edukasi door to door yang dilakukan pada keluarga pra sejahtera

\section{KESIMPULAN}

Edukasi kepada keluarga yang dilakukan dari rumah ke rumah (door to door) sangat efektif dilakukan untuk meningkatkan pengetahuan mengenai pencegahan penularan Covid-19. Terlihat dari meningkatnya pemahaman setelah dilakukan post test diakhir kegiatan edukasi. Kegiatan ini dapat dilakukan secara berkesinambungan sebagai upaya mengingatkan masyarakat agar jangan lengah dengan ancaman virus Corona yang belum berakhir. Untuk itu, diharapkan seluruh keluarga untuk selalu peka dan selalu mengingatkan dalam kehidupan bermasyarakat. Kerjasama dan koordinasi antar lintas sektor tentunya sangat dibutuhkan. Membentuk keluarga tangguh, cerdas dan peka lingkungan adalah kunci keberhasilan menanggulangi ancaman virus pada saat pandemi seperti ini.

\section{UCAPAN TERIMA KASIH}

Terimakasih kepada UP2M Fakultas Keperawatan Universitas Andalas sebagai penyandang dana sehingga kegiatan edukasi ini terlaksana dengan baik. Selanjutnya kepada wali nagari Sungai Buluh Selatan Kecamatan Batang Anai yang telah memberikan ijin sehingga kegiatan ini terlaksana.

\section{DAFTAR PUSTAKA}

Depkes RI. (2006). Keputusan Menteri Kesehatan Nomor 1193/Menkes/SK/ X/2004, dan didukung oleh Surat Keputusan Menteri Kesehatan Nomor 1114/Menkes/SK/VII/2005 tentang Pedoman Pelaksanaan Promosi Kesehatan di Daerah. Pusat Promkes Depkes RI, Jakarta.

Davies, A., Thompson, K. A., Giri, K., Kafatos, G., Walker, J., \& Bennett, A. (2013). Testing the efficacy of homemade masks: would they protect in an influenza pandemic? Disaster Medicine and Public Health Preparedness, 7(4), 413-418. 
https://doi.org/10.1017/dmp.2013.43

Dwiyanto, A. (1998). Validitas dan Reuabiutas Pengukuran Keluarga Sejahtera. 9(1).

Hayward, A., Beale, S., Johnson, A. M., Fragaszy, E. B., \& Watch, F. (2020). The Lancet Hand and Respiratory Hygiene Practices and the Risk and Transmission of Human Coronavirus Infections in a UK Community Cohort Hand and Respiratory Hygiene Practices and the Risk and Transmission of Human Coronavirus Infections in a UK Community.

Kristianingsih, A., Mukhlis, H., \& Ermawati, E. (2019). Wellness and healthy magazine. 1(February), 41-47. https://wellness.journalpress.id/wellness/article/view/v1i218wh

Maulana. (2009). Promosi Kesehatan. EGC.

Notoadmodjo, S. (2003). Pendidikan dan Perilaku Kesehatan. Rineka Cipta.

Pan, L., Mu, M., Ren, H. G., \& Yang, P. (2020). Clinical characteristics of COVID-19 patients with digestive symptoms in Hubei, China: a descriptive, cross-sectional, multicenter study. American Journal of Gastroenterology.

Pangestika, R., Fadli, R. K., \& Alnur, R. D. (2019). Edukasi Pencegahan Penularan Penyakit Tb $\begin{array}{lllll}\text { melalui Kontak Serumah. } & \text { Jurnal }\end{array}$ https://doi.org/10.29405/solma.v8i2.3258

Tim Gugus Tugas Percepatan Penanganan COVID-19. (2020). Penanganan Cepat Medis dan Kesehatan Masyarakat Covid-19 di Indonesia. www.covid19.go.id

Wang, Z, Qiang, w., Ke, H. (2020). A Handbook of 2019-nCoV Pneumonia Control and Prevention. Hubei Science and Technology Press.

World Health Organization (WHO). (2020). Global surveillance for human infection with novel coronavirus (2019-ncov). Http;//Www.Who.Int/Publications-Detail/Global-Surveillance-forHuman-Infection-with-Novel-Coronavirus-(2019-Ncov). 